\title{
Vodní měkkýši Malé Bečvy (Česká republika) Aquatic molluscs of the Malá Bečva River (Czech Republic)
}

\author{
LUBOŠ BERAN \\ Agentura ochrany přirody a krajiny ČR, Správa Chráněné krajinné oblasti Kokořinsko, Česká 149, CZ-27601 Mělník, \\ e-mail:lubos.beran@nature.cz
}

BerAn L., 2007: Vodní měkkýši Malé Bečvy (Česká republika) [Aquatic molluscs of the Malá Bečva River (Czech Republic)]. - Malacologica Bohemoslovaca, 6: 29-34. Online serial at $<$ http://mollusca.sav.sk> 7-Sep-2007.

\begin{abstract}
This paper brings a review of a malacological survey of Malá Bečva River (Central Moravia, Czech Republic). Malá Bečva is a canal $18 \mathrm{~km}$ long and approximately $7 \mathrm{~m}$ wide, which runs from the Bečva River near Troubky and flows into the Mostěnka stream (influent to the Bečva River) in altitude $190 \mathrm{~m}$. Aquatic molluscs sites were studied in 2007 at 9 sites. Altogether 23 species of aquatic molluscs $(9$ gastropods, 14 bivalves) were found. Except non-native species Potamopyrgus antipodarum, which is rare in Moravia, only the occurrence of common and widespread gastropods was documented, while research based on bivalves provided more interesting results. Large populations of three endangered species Unio crassus, Pisidium amnicum, and P. moitessierianum were documented. Population of Unio crassus was estimated at 5000-20000 individuals. This species and also Pisidium amnicum occurred only in the upper part of the Malá Bečva River from Troubky to Chropyně. Aquatic malacofauna of this part showed similarity with Strhanec Canal, which is canal of the Bečva River situated less than $10 \mathrm{~km}$ upstream of the Malá Bečva River. Bivalves Unio tumidus, Sinanodonta woodiana, Sphaerium rivicola, S. corneum and also Anodonta cygnea and Pseudanodonta complanata occur only downstream of Chropyně. This change of the malacofauna is probably caused by high nutrient tributary flows into the Malá Bečva River near Chropyně.
\end{abstract}

Key words: Mollusca, Malá Bečva River, faunistics, Unio crassus

\section{Úvod}

Hlavním impulsem pro tento průzkum se stala informace od L. Merty, pracovníka Agentury ochrany př́irody a krajiny ČR - středisko Olomouc, o výskytu celoevropsky ohroženého a zároveň evropsky významného druhu mlže velevruba tupého (Unio crassus). Nedávno provedený průzkum náhonu Bečvy Strhanec (BERAN 2003), který je situován relativně nedaleko proti proudu Bečvy, zároveň dával spolu s publikovanými nálezy zavlečené škeble asijské ( $\mathrm{Si}$ nanodonta woodiana) v Malé Bečvě u Chropyňského rybníka (NovÁK 2004) předpoklad pro zajímavé výsledky, což se následným průzkumem potvrdilo.

\section{Materiál a metodika}

Údaje o současném rozšiřrení použité v této práci jsou získané terénním průzkumem autora. Průzkum byl proveden v roce 2007 na 9 lokalitách průběžně na celém toku Malé Bečvy. Pozornost byla věnována zejména mlžům čeledi Unionidae. Sběr byl na většině lokalit prováděn kombinací vizuální metody a odběrů sedimentu za pomoci kovového kuchyňského cedníku (průměr $20 \mathrm{~cm}$, velikost ok 0,5-1 mm).
Získaný materiál byl ve většině případů determinován na místě a vrácen na lokalitu. V případě vzácných druhů (v tomto případě Unio crassus, Sinanodonta woodiana, Pisidium moitessierianum) byla část sběrů uložena do sbírky autora. U druhů determinovatelných pouze pomocí lupy (napřr. většina druhů r. Pisidium) byl materiál determinován až v laboratoři. Žádní jedinci nebyli determinováni pomocí pitvy, resp. to nebylo zapotřebí. Systém a nomenklatura jsou převzaty z práce BERAN (2002) a upraveny podle aktuální verze přehledu měkkýšů ČR (JUŘIČKOVÁ et al. 2007).

\section{Charakteristika území}

Malá Bečva (Obr. 1) je 18 km dlouhým kanálem odvádějícím vodu z Bečvy u Troubek (199 m n.m.), který ústí do Moštěnky u Plešovce $v$ nadmořské výšce 190 m (VLČEK 1984). Šířka toku se pohybuje kolem 7 $\mathrm{m}$, dno a břehy jsou $\mathrm{v}$ místech s nízkou rychlostí proudu převážně bahnité (větší část toku), v místech s rychlejším prouděním písčito-bahnité, písčité až štěrkopísčité. 


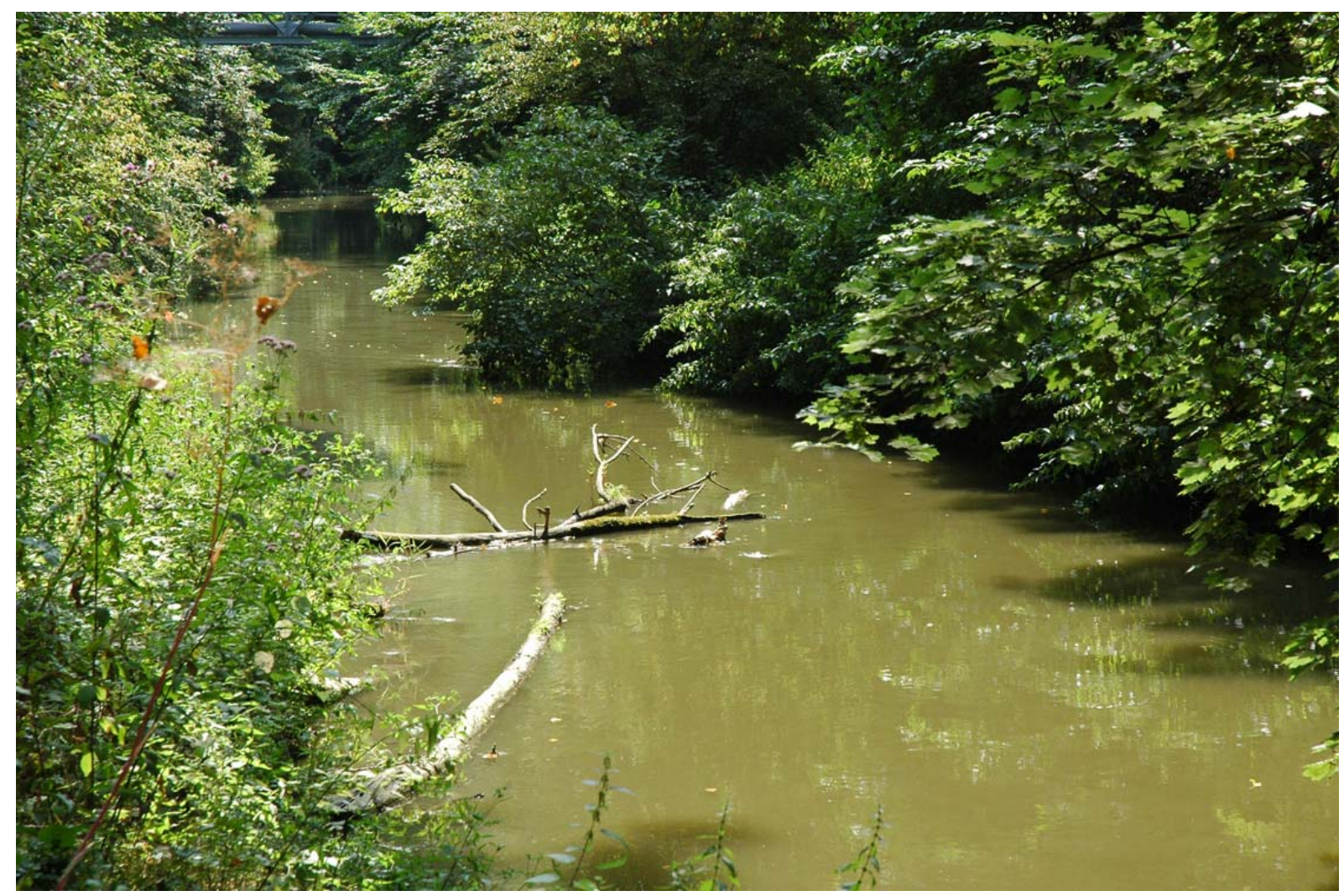

Obr. 1. Malá Bečva podél NPR Zástudánčí. Foto J. Šafářr.

Fig. 1. Malá Bečva River along Zástudánčí National Nature Reserve. Photo J. Šafár.

\section{Př̀ehled lokalit}

V této části jsou uvedeny popisy jednotlivých lokalit. Údaje jsou řazeny následovně: číslo lokality, zeměpisné souřadnice, kód pole pro faunistické mapování (BUCHAR 1982, PRUNER \& MíKA 1996), název nejbližší obce, lokalizace a popis lokality, datum průzkumu. Lokality jsou řazeny ve směru po proudu.

1 - 49²5'46" N, 17²0'19" E, 6570, Troubky, Malá Bečva pod mostem silnice Tovačov - Troubky, 3.6.2007; 2 - 49²4'42" N, 17019'50" E, 6569, Troubky, Malá Bečva u hájovny Drásov, 3.6.2007; 3 49²3'58" N, 17²18'59" E, 6669, Lobodice, Malá Bečva na západním okraji NPR Zástudánčí, 3.6.2007; 4 49²3'02" N, 17¹9'54" E, 6670, Zářičí, Malá Bečva západně od středu obce Záríčí u budovy, 3.6.2007; 5 $49^{\circ} 22^{\prime} 38^{\prime \prime} \mathrm{N}, 17^{\circ} 20^{\prime} 05^{\prime \prime}$ E, 6670, Zářičí, Malá Bečva západně od jižního okraje Zářičí, 3.6.2007; 6 49²1'55" N, 17²0'26" E, 6670, Chropyně, Malá Bečva asi $700 \mathrm{~m}$ nad železniční tratí Chropyně - Kojetín, 3.6.2007; 7 - 49 $21^{\prime} 15^{\prime \prime} \mathrm{N}, 1^{\circ} 21^{\prime 2} 27^{\prime \prime}$ E, 6670, Chropyně, Malá Bečva okolo mostu silnice Chropyně - Kojetín na jihozápadním okraji Chropyně, 14.7.2007; 8 - 49 $20^{\prime} 39^{\prime \prime} \mathrm{N}, 17^{\circ} 22^{\prime} 25^{\prime \prime} \mathrm{E}, 6670$, Plešovec, Malá Bečva u mostku pod soutokem Malé Bečvy a kanálu severozápadně od Plešovce,

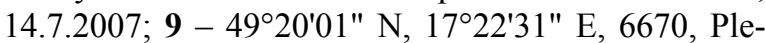
šovec, Malá Bečva jihozápadně od Plešovce asi $1 \mathrm{~km}$ nad ústím do Moštěnky, 14.7.2007.

\section{Výsledky a diskuse}

\section{Přehled zjištěných druhů}

V této části jsou uvedeny výsledky průzkumu podle jednotlivých druhů. U každého druhu je uveden kromě latinského názvu i český ekvivalent a zoogeografické rozšíření převzaté z práce BERAN (2002). Jsou zde uvedeny také údaje týkající se obývaných stanovišt', poznámky k rozširíení na území ČR a rozšíření ve sledované oblasti. Př́tomnost všech druhů na jednotlivých lokalitách včetně odhadovaných početností udává Tab. 1.

Tř́ída: Gastropoda

Řád: Architaenioglossa

Čeled': Viviparidae

Viviparus contectus (Millet, 1813) - bahenka živorodá. Evropsko-západosibiřský druh. Druh vázaný na nivy větších řek a rybniční oblasti, kde obývá hustěji zarostlé stojaté až mírně tekoucí vody. Výskyt byl zjištěn pouze na jediné lokalitě.

Řád: Neotaenioglossa

Čeled': Hydrobiidae

Potamopyrgus antipodarum (Gray, 1843) - písečník novozélandský. Druh zavlečený do Evropy z Nového Zélandu. V současnosti běžný a šiŕící se druh zejména v Polabí a severozápadních Čechách, na Moravě je za- 
tím relativně vzácný. Obývá především pískovny, odstavená ramena a vodní toky se štěrkopísčitými sedimenty. Zoologicky významný nález, který dokládá další šíření druhu i v oblasti Moravy. Zjištěn byl v horní části Malé Bečvy.

Čeled': Bithyniidae

Bithynia tentaculata (Linnaeus, 1758) - bahnivka rmutná. Palearktický druh. Běžný druh pomaleji tekoucích a úživnějších vodních toků a nepř́liš zazemněných a zarostlých stojatých vod. Spolu s předchozím druhem je nejčastěji nalezeným plžem Malé Bečvy, který byl zjištěn na 6 zkoumaných lokalitách.

Rád: Hygrophila

Čeled': Acroloxidae

Acroloxus lacustris (Linnaeus, 1758) - člunice jezerní. Palearktický druh. Běžný obyvatel především větších stojatých případně pomaleji tekoucích vod, který byl zjištěn na jediné lokalitě.

Čeled': Lymnaeidae

Galba truncatula (O.F. Müller, 1774) - bahnatka malá. Holarktický druh. Běžný druh, který se obvykle vyskytuje na rozhraní mezi vodou a souší (břehy vodních toků, mokřady). Zjištěn byl na březích Malé Bečvy na 3 lokalitách lze však předpokládat, že bude hojnější.

Radix auricularia (Linnaeus, 1758) - uchatka nadmutá. Palearktický druh. Obývá velké spektrum biotopů kromě př́liš zarostlých a zazemněných stojatých vod. Je typickým pionýrským druhem obnovených či nově vytvořených biotopů (pískovny). Běžný je i výskyt v pomaleji tekoucích vodách. V Malé Bečvě byl zjištěn na 2 lokalitách.

Radix cf. ampla (Hartmann, 1821) - uchatka široká. Palearktický druh. Plž charakteristický pro větší vodní toky. Stejně jako předchozí druh byl zjištěn na dvou lokalitách. Taxonomie rodu Radix není prozatím spolehlivě dořešena a i př́slušnost nalezených jedinců k druhu $R$. ampla není jistá.

Čeled': Planorbidae

Gyraulus albus (O.F. Müller, 1774) - kružník bělavý. Palearktický druh. Běžný druh na většině území ČR, který obývá široké spektrum biotopů a to zejména méně zarostlých. Je běžně zjišt'ován i v pomaleji tekoucích vodách. V Malé Bečvě byl nalezen na jediné lokalitě.

Ancylus fluviatilis O.F. Müller, 1774 - kamomil říční. Evropský druh. Druh tekoucích vod, který byl zjištěn jen na třech lokalitách s ohledem na skutečnost, že Malá Bečva je spíše pomalu tekoucím zabahněným kanálem, kde jsou proudné úseky s většími kameny (biotop kamomila) relativně vzácné.
Třída: Bivalvia

Rád: Unionoida

Čeled': Unionidae

Unio pictorum (Linnaeus, 1758) - velevrub malířský.

Evropský druh. Nejběžnější zástupce rodu Unio v České republice, který byl nalezen na všech zkoumaných lokalitách a obvykle byl nejpočetněji zastoupeným velkým mlžem. Na rozdíl od velevruba tupého se vyskytoval i dále od břehu (ve větších hloubkách).

Unio tumidus Philipsson 1788) - velevrub nadmutý. Evropský druh. Vzácnější př́íslušník rodu Unio preferující úživnější pomaleji tekoucí až stojaté vody v nivách větších řek. Jeho výskyt v Malé Bečvě je omezen na dolní část pod Chropyní. V tomto úseku je však relativně početný (zhruba stejně jako velevrub malířský).

Unio crassus Philipsson, 1788 - velevrub tupý. Evropský druh. Celoevropsky ohrožený a zároveň evropsky významný druh, který obývá různě velké toky. V současnosti je známo v ČR asi 15 lokalit s perspektivními populacemi (např. BERAN 2002). V Malé Bečvě byla zjištěna početná populace v horním úseku Malé Bečvy po Chropyni. Výskyt je koncentrován zejména $\mathrm{v}$ úrovni obou břehů (asi do 0,5 $\mathrm{m}$ od břehu), v některých (mělčích, prudších) místech i dále do koryta. Místy početnost přesahuje i 1 jedince na $1 \mathrm{~m}^{2}$ (blíže viz Tab. 2). Celkový odhad velikosti populace v cca $10 \mathrm{~km}$ dlouhém úseku Malé Bečvy je 5000-20000 jedinců. Populace je místy (tak jako na řadě jiných lokalit) decimována ondatrou pižmovou (Ondatra zibethicus). Na některých lokalitách však byly nalezeny i čerstvé schránky zlikvidované evidentně jiným živočichem. Na rozdíl od schránek po konzumaci ondatrou, které jsou otevřené a obvykle téměř nepoškozené (škeble mohou být okousány), byly některé schránky poškozené ukousnutím části schránky v okolí přijímacího a vyvrhovacího otvoru (viz Obr. 2). Na základě informací kolegy z AOPK ČR - středisko Olomouc (J. Šafář) o výskytu mývala severního (Procyon lotor) v tomto území je pravděpodobné, že mlži jsou konzumováni mývalem severním, nebot' v ČR nebyl tento způsob konzumování velkých mlžů zatím nikde jinde autorem pozorován. Výskyt početné populace velevruba tupého je z pohledu ochrany př́rody velmi významný a zároveň spolu s předchozími průzkumy náhonu Strhanec (BERAN 2003) a autorovými dosud nepublikovanými průzkumy náhonu v Hovězí a Vsetíně dokládá vhodnost náhonů či kanálů na Bečvě pro tento druh.

Anodonta cygnea (Linnaeus, 1758) - škeble rybničná. Eurosibiřský druh. V současnosti již vzácnější druh obývající odstavená ramena, tůně a vodní nádrže. Druh je zařazen v Červeném seznamu vodních měkkýšů ČR mezi druhy zranitelné (BERAN et al. 2005, BERAN 2002). Z pohledu ochrany př́rody významný druh, zařazený mezi zvláště chráněné druhy. V Malé Bečvě byl ojediněle nalezen pouze na jediné lokalitě v dolním úseku. 


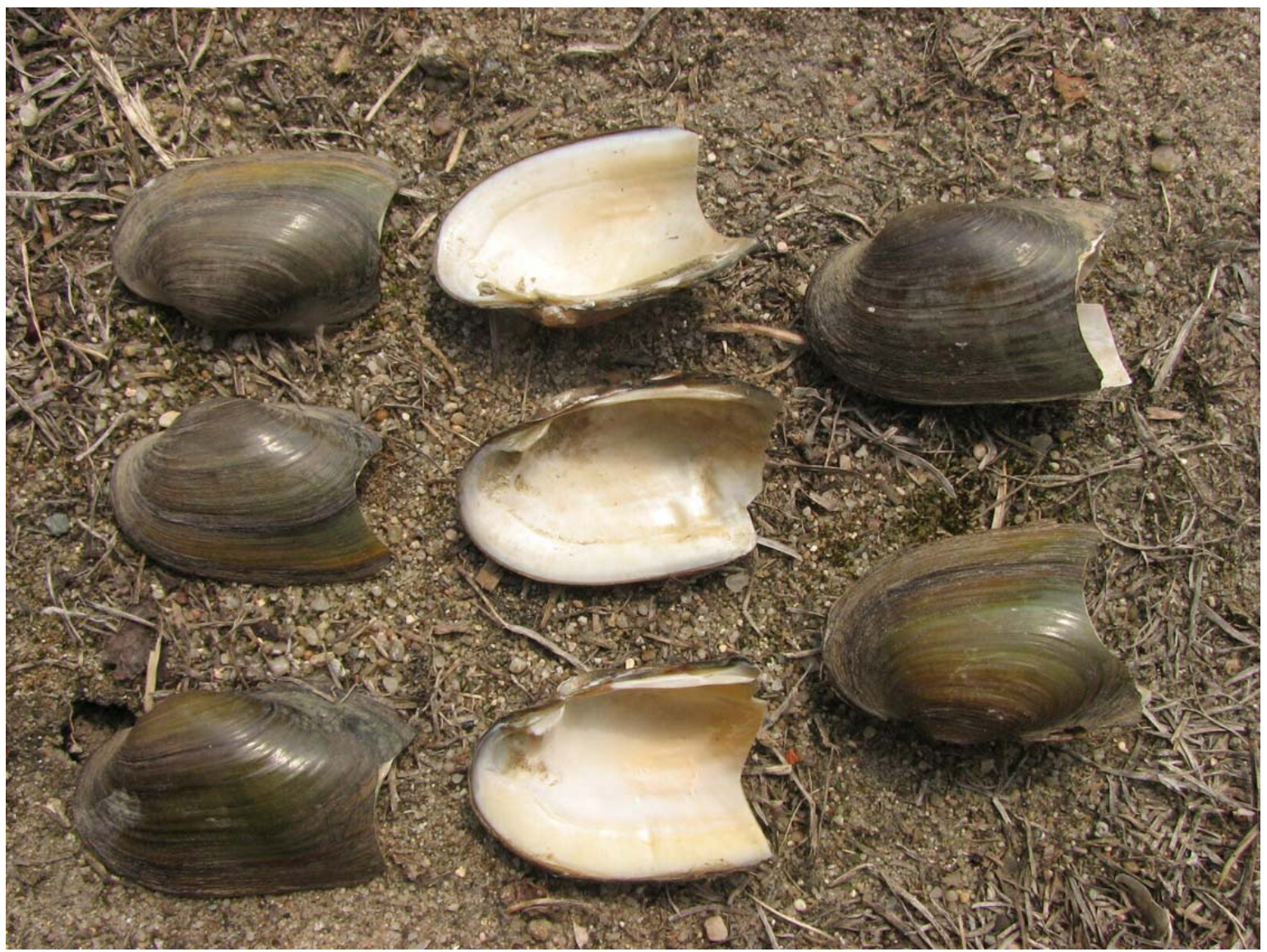

Obr. 2. Schránky Unio crassus po predaci mývalem severním (Procyon lotor).

Fig. 1. Conchs of Unio crassus after predation of Procyon lotor.

Anodonta anatina (Linnaeus, 1758) - škeble ř́iční. Eurosibiřský druh. Zřejmě nejběžnější velký mlž v rámci ČR, vyskytující se v tekoucích i větších stojatých vodách. V Malé Bečvě patř́i spolu s velevrubem malířským k nejpočetněji zastoupeným velkým mlžům a byla zjištěna na všech zkoumaných lokalitách.

Pseudanodonta complanata (Rossmäessler, 1835) škeble plochá. Evropský druh. Vzácný a ohrožený obyvatel větších nížinných vodních toků, který se obvykle vyskytuje v nízkých abundancích. Zjištěn byl na jediné lokalitě v dolním úseku Malé Bečvy.

Sinanodonta woodiana (Lea, 1834) - škeble asijská. Původně asijský druh zavlečený do Evropy. Vzácný druh s ojedinělými nálezy $\mathrm{v}$ Čechách a více údaji z oblasti střední a jižní Moravy. Výskyt v Malé Bečvě u Chropyně byl prokázán již před několika lety (NovÁK 2004) a tak zjištění tohoto druhu nebylo velkým překvapením. Nalezena byla na všech 3 lokalitách pod Chropyní.

\section{Řá: Veneroida}

Čeled': Sphaeriidae

Sphaerium rivicola (Lamarck, 1818) - okružanka říční. Evropský druh. Mlž obývající větší a živinami bohatší vodní toky. Zjištěn byl na všech lokalitách na dolním úseku pod Chropyní.

Sphaerium corneum (Linnaeus, 1758) s. lat. - okružanka rohovitá. Palearktický druh (taxon). Velmi častý mlž žijící především v živinami bohatých pomaleji tekoucích vodách, který byl opět zjištěn na všech lokalitách na dolním toku Malé Bečvy.

Musculium lacustre (O.F. Müller, 1774) - okrouhlice rybničná. Holarktický druh. V ČR mozaikovitě rozšířený druh, který obývá pomaleji tekoucí a stojaté vody. Při průzkumu Malé Bečvy byl nalezen na 4 lokalitách.

Pisidium amnicum (O.F. Müller, 1774) - hrachovka říční. Palearktický druh. Velmi vzácný druh vyskytující se ve vodních tocích s písčitobahnitým dnem. Na Moravě druh prakticky vymizel (cf. BERAN 2002) a zjištěný výskyt je spolu s náhonem Strhanec (BERAN 2003) jedinou v současnosti známou moravskou lokalitou s početnější populací. Zjištěn byl v Malé Bečvě nad Chropyní (5 lokalit).

Pisidium henslowanum (Sheppard, 1823) - hrachovka hrbolatá. Holarktický druh. Relativně běžný druh vyskytující se především v tekoucích vodách a odstavených ramenech řek $\mathrm{v}$ nižších polohách. Zjištěn byl v bahnitých a písčitobahnitých sedimentech na většině (8) lokalit.

Pisidium supinum A. Schmidt, 1851 - hrachovka obrácená. Palearktický druh. Vzácnější obyvatel vodních toků, který byl zjištěn na 2 lokalitách.

Pisidium subtruncatum Malm, 1855 - hrachovka otupená. Holarktický druh. Jedna z nejběžnějších hracho- 
vek žijící především ve vodních tocích, ale také v řadě typů stojatých vod. Zjištěna byla na všech lokalitách.

Pisidium nitidum Jenyns, 1832 - hrachovka lesklá. Holarktický druh. Opět poměrně běžný druh nalezený na 8 lokalitách.

Pisidium casertanum (Poli, 1791) - hrachovka obecná. Pravděpodobně kosmopolitní druh. Zřejmě nejběžnější hrachovka rodu Pisidium v ČR, která se vyskytuje v rradě vodních stanovišt' od prameništ' a mokřadů až po velké vodní toky. Ve zkoumaném území zjištěna na 5 lokalitách.
Pisidium moitessierianum (Paladilhe, 1866) - hrachovka nepatrná. Evropský druh. Vzácný druh, který je znám na Moravě pouze z jižní části Dolnomoravského úvalu (cf. BERAN 2002). Malá Bečva a náhon Bečvy Strhanec (BERAN 2003) jsou jedinými známými lokalitami na území střední Moravy. Vyskytuje se $\mathrm{v}$ písčitobahnitých sedimentech pomaleji tekoucích vodních toků a v Malé Bečvě byl zjištěn na 8 lokalitách.

Tabulka 1. Přehled vodních měkkýšů podle lokalit. Latinský název, jméno autora a datum popisu, kategorie dle Červeného seznamu vodních měkkýšů ČR (BERAN et al. 2005, BERAN 2002). $\Sigma$ - počet lokalit každého druhu.

Table 1. List of aquatic molluscs according to number of locality. Latin name, its author and date of description, categories according to the Red List of aquatic molluscs of the Czech Republic (adopted from BERAN et al. 2005, BERAN 2002). $\Sigma-$ number of localities of each species.

\begin{tabular}{|c|c|c|c|c|c|c|c|c|c|c|c|}
\hline Druh & Kategorie ohrožení & 1 & 2 & 3 & 4 & 5 & 6 & 7 & 8 & 9 & $\Sigma$ \\
\hline Viviparus contectus (Millet, 1813) & zranitelný (VU) & & & & & & 3 & & & & 1 \\
\hline Potamopyrgus antipodarum (Gray, 1843) & nevyhodnocený (NE) & 80 & 8 & 100 & 35 & 50 & 7 & & & & 6 \\
\hline Bithynia tentaculata $($ Linnaeus, 1758$)$ & málo dotčený (LC) & 25 & 2 & 3 & & & & 65 & 25 & 8 & 6 \\
\hline Acroloxus lacustris (Linnaeus, 1758) & málo dotčený (LC) & & & & & & & & 15 & & 1 \\
\hline Galba truncatula (O.F. Müller, 1774) & málo dotčený (LC) & & 200 & & & & & & 8 & 3 & 3 \\
\hline Radix auricularia (Linnaeus, 1758) & málo dotčený (LC) & 10 & & & & 1 & & & & & 2 \\
\hline Radix cf. ampla (Hartmann, 1821) & téměř ohrožený (NT) & 15 & 1 & & & & & & & & 2 \\
\hline Gyraulus albus (O.F. Müller, 1774) & málo dotčený (LC) & 1 & & & & & & & & & 1 \\
\hline Ancylus fluviatilis O.F. Müller, 1774 & ný (LC) & 8 & & & & & & 3 & 6 & & 3 \\
\hline Unio pictorum (Linnaeus, 1758) & málo dotčený (LC) & 3 & 5 & 20 & 35 & 120 & 25 & 20 & 14 & 14 & 9 \\
\hline Unio tumidus Philipsson, 1788 & zranitelný (VU) & & & & & & & 25 & 9 & 11 & 3 \\
\hline Unio crassus Philipsson, 1788 & ohrožený (EN) & 1 & 9 & 5 & 3 & 8 & 1 & & & & 6 \\
\hline Anodonta cygnea (Linnaeus, 1758) & zranitelný (VU) & & & & & & & 2 & & & 1 \\
\hline Anodonta anatina (Linnaeus, 1758) & málo dotčený (LC) & 4 & 6 & 15 & 9 & 30 & 10 & 50 & 7 & 8 & 9 \\
\hline Pseudanodonta complanata (Rossmäes & ohrožený ( & & & & & & & 1 & & & 1 \\
\hline Sinanodonta woodiana (Lea, 1834) & nevyhodnocený (NE) & & & & & & & 7 & 1 & 4 & 3 \\
\hline Sphaerium rivicola $($ Lamarck, 1818$)$ & téměř ohrožený (NT) & & & & & & & 6 & 2 & 4 & 3 \\
\hline Sphaerium corneum (Linnaeus, 1758) s. lat. & málo dotčený (LC) & & & & & & & 4 & 6 & 3 & 3 \\
\hline Musculium lacustre (O.F. Müller, 1774) & téměř ohrožený (NT) & 2 & 3 & 10 & & & & 2 & & & 4 \\
\hline Pisisidium amnicum (O.F. Müller, 1774) & ohrožený (EN) & & 20 & 25 & 12 & 10 & 40 & & & & 5 \\
\hline Pisidium henslowanum (Sheppard, 1823) & málo dotčený (LC) & & 3 & 8 & 6 & 12 & 1 & 15 & 4 & 5 & 8 \\
\hline Pisidium supinum A. Schmidt, 1851 & téměř ohrožený (NT) & 3 & 2 & & & & & & & & 2 \\
\hline Pisidium subtruncatum Malm, 1855 & málo dotčený (LC) & 5 & 15 & 30 & 20 & 25 & 30 & 4 & 2 & 4 & 9 \\
\hline Pisidium nitidum Jenyns, 1832 & málo dotčený (LC) & 1 & 8 & 6 & & 6 & 4 & 3 & 2 & 2 & 8 \\
\hline Pisidium casertanum (Poli, 1791) & málo dotčený (LC) & & 5 & 2 & 3 & 1 & 3 & & & & 5 \\
\hline Pisidium moitessierianum (Paladilhe, 1866) & ohrožený (EN) & & 10 & 20 & 7 & 6 & 10 & 30 & 8 & 8 & 8 \\
\hline Celkem & & 13 & 15 & 12 & 9 & 11 & 11 & 15 & 14 & 12 & \\
\hline
\end{tabular}

Tabulka 2. Početnost velkých mlžů na vybraných plochách. První sloupec - početnost velkých mlžů na jednotlivých plochách rozdílné velikosti podle místních podmínek. Druhý sloupec - početnost velkých mlžů přepočtená na $1 \mathrm{~m}^{2}$.

Table 2. Abundance of unionids on the selected sites. First column - abundance of unionids on the particular place with different size according to local conditions. Second column - abundance of unionids counted per $1 \mathrm{~m}^{2}$.

\begin{tabular}{|l|cc|cc|cc|cc|cc|cc|}
\hline \multicolumn{1}{|c|}{ lokalita } & \multicolumn{2}{|c|}{$\mathbf{2}$} & \multicolumn{2}{c|}{$\mathbf{3}$} & \multicolumn{2}{c|}{$\mathbf{4}$} & \multicolumn{2}{c|}{$\mathbf{5}$} & \multicolumn{2}{c|}{$\mathbf{7}$} & \multicolumn{2}{c|}{$\mathbf{8}$} \\
\hline & $5 \mathrm{~m}^{2}$ & $1 \mathrm{~m}^{2}$ & $3 \mathrm{~m}^{2}$ & $1 \mathrm{~m}^{2}$ & $2,5 \mathrm{~m}^{2}$ & $1 \mathrm{~m}^{2}$ & $10 \mathrm{~m}^{2}$ & $1 \mathrm{~m}^{2}$ & $2 \mathrm{~m}^{2}$ & $1 \mathrm{~m}^{2}$ & $6 \mathrm{~m}^{2}$ & $1 \mathrm{~m}^{2}$ \\
\hline Unio crassus & 9 & 1,8 & 3 & 1 & 3 & 1,2 & 8 & 0,8 & & & & \\
\hline Unio tumidus & & & & & & & & & 10 & 5 & 9 & 1,5 \\
\hline Unio pictorum & 5 & 1 & 11 & 3,7 & 35 & 14 & 120 & 12 & 8 & 4 & 14 & 2,3 \\
\hline Anodonta cygnea & & & & & & & & & & & & \\
\hline Anodonta anatina & 6 & 1,2 & 6 & 2 & 9 & 3,6 & 30 & 3 & 16 & 8 & 7 & 1,2 \\
\hline Pseudanodonta complanata & & & & & & & & & 1 & 0,5 & & \\
\hline Sinanodonta woodiana & & & & & & & & & 4 & 2 & 1 & 0,2 \\
\hline Celkem & 20 & 4 & 20 & 6,7 & 47 & 18,8 & 158 & 15,8 & 39 & 19,5 & 31 & 5,2 \\
\hline
\end{tabular}


Průzkum Malé Bečvy v roce 2007 doložil výskyt 23 druhů vodních měkkýšů ( 9 plžů, 14 mlžů). V případě plžů se jedná o druhy celkem běžné a jejich počet je relativně nízký. Zajímavý je zejména výskyt zavlečeného druhu Potamopyrgus antipodarum, který je na Moravě prozatím vzácný. Mnohem zajímavější jsou však společenstva mlžů. Celkem zde bylo zjištěno více než 50 \% našich mlžů, což je s ohledem na skutečnost, že se jedná prakticky o jediný biotop (menší a pomalu tekoucí vodní tok) číslo neobvykle vysoké. I složení společenstva mlžů je velmi zajímavé a zjištěn byl výskyt řady významných druhů. Nález hrachovek Pisidium amnicum a P. moitessierianum patří k velmi významným a v př́padě prvního druhu spolu s náhonem Strhanec (BERAN 2003) prakticky jediným na Moravě. Významný je výskyt početné populace evropsky významného druhu Unio crassus, jehož populace je zde odhadována na 5000-20000 jedinců. V dolní části Malé Bečvy byl zjištěn respektive potvrzen výskyt zavlečeného druhu Sinanodonta woodiana. Nejzajímavějším zjištěním je však výrazná změna společenstva mlžů, ke které dochází zhruba na úrovni Chropyně, kdy mizí druhy Unio crassus, Pisidium amnicum a objevují se druhy Unio tumidus, Sinanodonta woodiana, Sphaerium rivicola, S. corneum a ojediněle také Anodonta cygnea a Pseudanodonta complanata. Důvodem k tak výrazné změně společenstva je zřejmě ústí různých př́toků, kanálů apod., odtékajících mimo jiné z rybníků včetně Chropyňského rybníka a měnící tak charakter a kvalitu vodního prostředí - zvýšení obsahu živin a s tím související jevy.

\section{Závěr}

Průzkum kanálu Malá Bečva zjistil či potvrdil výskyt řady významných druhů vodních měkkýšů, respektive mlžů a zejména s ohledem na výskyt silných populací druhů Unio crassus, Pisidium amnicum, P. moitessierianum si zaslouží pozornost a ochranu před negativ- ními vlivy (znečištění vody, zásahy do koryta a vodního režimu).

Poděkování. L. Mertovi (AOPK ČR, středisko Olomouc) děkuji za poskytnutí prvotní informace o výskytu druhu Unio crassus v Malé Bečvě.

\section{Literatura}

BERAN L., 2002: Vodní měkkýši České republiky - rozšiřrení a jeho změny, stanoviště, šíření, ohrožení a ochrana, červený seznam [Aquatic molluscs of the Czech Republic - distribution and its changes, habitats, dispersal, threat and protection, Red List]. - Sborník př́rodovědného klubu v Uh. Hradišti, Supplementum 10, 258 pp.

BERAN L., 2003: Vodní měkkýši náhonu Strhanec (střední Morava) [Aquatic molluscs of the Strhanec Canal (Central Moravia, Czech Republic)]. - Bulletin Lampetra V., ZO ČSOP Vlašim, 5: 22-26.

BERAN L., JuŘIČKOVÁ L. \& HorsáK M., 2005: Mollusca (Měkkýši), pp. 69-74. - In: Červený seznam ohrožených druhů České republiky. Bezobratlí. Red list of threatened species in the Czech Republic. Invertebrates, FARKAČ J., KRÁL D. \& ŠKORPíK M. (eds) Agentura ochrany přírody a krajiny ČR, Praha, 760 pp.

BUCHAR J., 1982: Způsob publikace lokalit živočichů Z území Československa. - Věst. Čs. Společ. Zool., Praha, 46: 317-318.

JuŘIČKOVÁ L., HoRsÁK M., BERAN L. \& DVOŘÁK L. 2007: Check-list of the molluscs (Mollusca) of the Czech Republic. - http://www.mollusca.sav.sk/malacology/checklist.htm NovÁK J., 2004: Třetí potvrzený nález škeble asijské v ČR

[The third Confirmed Record of the Sinanodonta woodiana in the Czech Republic]. - Živa, 52(1): 41.

PRUNER L. \& MíkA P., 1996: Seznam obcí a jejich částí v České republice s čísly mapových polí pro sítové mapování fauny [List of settlements in the Czech Republic with associated map field codes for faunistic grid mapping system]. - Klapalekiana, 32, Suppl.: 1-175.

VLČEK V. (ed.), 1984: Vodní toky a nádrže. - Zeměpisný lexikon ČSR. Academia, Praha, 316 pp. 